\title{
Placenta Tissue without Amniotic Elements
}

National Cancer Institute

\section{Source}

National Cancer Institute. Placenta Tissue without Amniotic Elements. NCI Thesaurus. Code C133341.

The placenta and tissue derived from the placenta (other than amniotic membrane). 